\title{
Exploring the Anti-inflammatory and Anti-cancer compounds from the leaves of Acalypha indica
}

\author{
${ }^{1}$ T. Reddy Prasad Reddy, ${ }^{1}$ R. Srinu Venkat Rao, ${ }^{2}$ A.V.N.Swamy, ${ }^{3}$ P.Reddanna, \\ ${ }^{3}$ G.Pulla Reddy, ${ }^{1}$ D.V.Rami Reddy \\ ${ }^{I}$ Department of Biotechnology, ALFA College of Engg. \& Tech., Allagadda (A.P.) India \\ ${ }^{2}$ Department of Chemical Engineering, J.N.T.U.Anantapur., Anantapur (A.P.) India \\ ${ }^{3}$ Department of Animal Biotechnology, Hyderabad Central University, Hyderabad (A.P) India
}

\begin{abstract}
Acalypha indica (Euphorbiaceae) is commonly known as Indian Copperleaf and Indian Nettle. It is a common annual herb, which grows in the hotter parts of India like Bihar, Assam and southwards of Kerala. The hexane and aqueous extracts of leaves were screened for antioxidant and anti-inflammatory compounds as evidenced by the potent inhibition of LOX, COX enzyme activity method, which showed significant percentage of inhibition in dose dependent manner. As antioxidant therapy is found to be useful in complicated disease status related with free radical activity, the present study might be extended for the formulation and evaluation of different antioxidant herbal dosage forms. Finally Hexane extract showed potent enzymatic inhibition to COX-1 with IC50-6.48 g g/ml. Ethyl acetate and ethanol soxhlation extracts IC50 values $16.43 \mu \mathrm{g} / \mathrm{ml}$ and $40.97 \mu \mathrm{g} / \mathrm{ml}$. Hexane, ethyl acetate and ethanol soxhlation extracts showed potent enzymatic inhibition to COX-2.Here aqueous extract showed moderate enzymatic inhibition. Hence the present study is taken upto systematically evaluate the anti-inflammatory and anti-cancer properties of the extracts and also to isolate and characterize the active principles of Acalypha indica.
\end{abstract}

Keywords: Acalypha indica, Lipoxygenase, Cyclooxygenase and Anti-inflammatory.

\section{Introduction}

Medicinal plants are extensively used to cure various infectious diseases in human. Now a days, several plants have been identified for their anticancer and anti-inflammatory compounds. Scientific experiments on the anticancer properties of plants and their components have been detected. Herbal medicines have been the basis of treatment and cure for various diseases and physiological conditions in traditional methods practiciced such as ayurveda, unani and siddha. However no systematic studies were conducted to evaluate the efficacy and safety of the formulations from the plant were undertaken. Also no attempts were made to isolate and identify the active principles involved in these effects.

\section{Inflammation}

Inflammation (Latin, inflammare, to set on fire) is part of the complex biological response of vascular tissues to harmful stimuli, such as pathogens, damaged cells, or irritants (Ferrero-Miliani et al., 2007). Inflammation is a protective attempt by the organism to remove the injurious stimuli and to initiate the healing process. Without inflammation, wounds and infections would never heal. Similarly, progressive destruction of the tissue would compromise the survival of the organism. However, chronic inflammation can also lead to a host of diseases, such as hay fever, atherosclerosis, and rheumatoid arthritis. It is for that reason that inflammation is normally closely regulated by the body. Inflammation can be classified as either acute or chronic. Acute inflammation is the Initial response of the body to harmful stimuli and is achieved by the increased movement of leukocytes (especially granulocytes) from the blood into the injured tissues. A cascade of biochemical events propagates and matures the inflammatory response, involving the local vascular system, the immune system, and various cells within the injured tissue. Prolonged inflammation, known as chronic inflammation, leads to a progressive shift in the type of cells present at the site of inflammation and is characterized by simultaneous destruction and healing of the tissue from the inflammatory process.

\section{Causes}

- Burns, Chemical irritants

- Frostbite

- Toxins

- Infection by pathogens

- Physical injury, blunt or penetrating

- Immune reactions due to hypersensitivity

- Ionizing radiation 
- Foreign bodies, including splinters, dirt and debris

\section{Eicosanoids}

In mammalian cells, Eicosanoid biosynthesis is usually initiated by the activation of phospholipase $\mathrm{A}_{2}$ and the release of Arachidonic acid (AA) from membrane phospholipids. The Arachidonic acid is subsequently transformed by cycloxygenase (COX) and Lipoxygenase(LOX) pathways to prostaglandins, thromboxane and leukotrienes. Eicosanoid production is considerably increased during inflammation. Eicosanoids, the oxygenated metabolites of eicosapolynoic fatty acids such as AA, have been the most actively studied of all physiological components contributing to inflammation (Williams and Higgs. 1988, Wymann and schneiter, 2008).AA generated from cellular membrane phospholipids gets oxygenated by either the COX pathway that generates prostaglandins (PGs) or the LOX pathway that forms hydroperoxy derivatives. In addition to COX and LOX pathways, AA is also oxygenated by the epoxygenase pathway involving cytochrome $\mathrm{P}^{45 \mathrm{~S}}$ to generate Epoxyeicosatrienoic acids (EETs).

\section{Materials \& Methods}

Plant collection: Mature leaves of Acalypha indica were collected from Tirumala at Chittoor district, Andhra Pradesh. Leaves were washed thoroughly three times with water and once with distilled water. The leaves were shade dried and powdered by grinder machine. The powdered samples were sealed in polythene bags until the time of extraction.

\section{In Vitro Enzyme assays}

For Screening of extracts against to 5-LOX, 15-LOX and COX-1, COX-2, the concentrations were taken in the respective way, $100 \mu \mathrm{g} / \mathrm{mL}, 10 \mu \mathrm{g} / \mathrm{mL}$ and $1 \mu \mathrm{g} / \mathrm{mL}$ as final concentration.

\section{In vitro 5-LOX and 15-LOX Enzyme assays}

Polarographic method was used to measure the enzyme activity with a CLARK's method oxygen electrode on Gilson model 5/6 oxygraph. Typical reaction mixture contained $3 \mathrm{ml}$ with assay buffer, distilled water and enzyme and AA. Since Lipoxygenases are oxygen-consuming enzymes, the concentration of oxygen decrease in the reaction mixture and the rate of decrease in oxygen were taken as a measure of enzyme activity. Reaction was allowed to proceed at $25^{\circ} \mathrm{C}$ and from the curve recorded the difference in oxygen concentration per minute was taken for calculating enzyme activity. The initial and final concentrations were recorded on the oxygraph. One unit of enzyme activity is defined as $1 \mu$ mole of oxygen consumed $/ \mathrm{min}$ and $\mathrm{IC}_{50}$ values were calculated. Typical reaction mixture contains.

1. $150 \mathrm{mM}$ phosphate buffer ( $\mathrm{pH} 6.3)-2 \mathrm{~mL}$

2. Distilled water $-910 \mu 1$

3. Enzyme (5-LOX/15-LOX) $-50 \mu 1$

4. Compound (crude extract) $-30 \mu 1$

5. Arachidonic acid $-40 \mathrm{mM} 10 \mu \mathrm{l}$

Total- $3 \mathrm{ml}$

Enzyme activity was calculated using the equation:

ENZYME ACTIVITY $=\left[\left(\right.\right.$ Micromole $\mathrm{O}_{2}$ incorporated $\left./ \mathrm{min}\right) / \mathrm{ml}$ of enzyme used]

$\mu$ Mole of $\mathrm{O} 2$ incorporated $(\mu \mathrm{moles} / \mathrm{min} / \mathrm{ml})=\left[\right.$ Initial $\mathrm{O}_{2}$ conc. - Final $\mathrm{O}_{2}$ conc. $]$

Reaction mixture for enzyme activity

Buffer $2 \mathrm{~mL}+$ Water-940 $\mu \mathrm{l}+$ Enzyme-50 $\mu \mathrm{l}+\mathrm{AA} 10 \mu \mathrm{l}$

Reaction mixture with extract

Buffer $2 \mathrm{ml}+$ Water-910 $\mu \mathrm{l}+$ Enzyme-50 $\mu \mathrm{l}+$ Extract-30 $\mu \mathrm{l}+$ AA $10 \mu \mathrm{l}$

Cell culture and treatment

\section{Cell Culture}

The human squmous skin cancerous cell line A431 was obtained from National Centre for Cell Science (NCCS), Pune, India and maintained in DMEM supplemented with $10 \%$ heat inactivated FBS, $100 \mathrm{IU} / \mathrm{mL}$ penicillin, $100 \mu \mathrm{g} / \mathrm{mL}$ streptomycin and $2 \mathrm{mM}$ L-Glutamine and maintained in a humidified atmosphere with $5 \% \mathrm{CO}_{2}$ at $37^{\circ} \mathrm{C}$. The cells were sub-cultured twice each week and the exponentially growing cells were used in all treatments. Different extracts of $A$. indica dissolved in DMEM and DMSO respectively were used in the treatments. $10 \mathrm{mg} / \mathrm{mL}$ stock of extracts was employed in this study. 


\section{Treatment of cells}

At the time of treatment, working solutions were diluted accordingly in DMEM. Final concentrations of different extracts were ranged from $1 \mu \mathrm{g} / \mathrm{mL}$ to $500 \mu \mathrm{g} / \mathrm{mL}$ and . The drugs were added to the cells, $24 \mathrm{hr}$ of seeding in $100 \mathrm{mM}$ Petri dish. The final concentration of the vehicle (DMSO) never exceeded $0.05 \%$. A431 cells exposed to $0.1 \%$ DMSO served as controls.

Yields of Acalypha indica leaf extracts

\section{Results \& Discussion}

$100 \mathrm{gm}$ of shade dried leaf powder of Acalypha indica had yielded the following amount of each of the extracts when the solvents, hexane, ethyl acetate, methanol were used in the increasing order of polarity from hexane to water during Soxhlation and soaking method.

Table 1: Yields of Acalypha indica leaf extracts

\begin{tabular}{|c|c|c|}
\hline \multirow{4}{*}{ Plant } & Solvent & Extract after evap./lyoph.(gm) \\
\hline \multirow{4}{*}{ Acalypha indica } & Hexane (Soxhlation) & 3.46 \\
\cline { 2 - 3 } & Ethyl acetate (Soxhlation) & 0.14 \\
\cline { 2 - 3 } & Ethanol (Soxhlation) & 11.54 \\
\cline { 2 - 3 } & Ethanol (soaking) & 5.86 \\
\cline { 2 - 3 } & Methanol (Soxhlation) & 4.85 \\
\cline { 2 - 3 } & Methanol (soaking) & 9.66 \\
\cline { 2 - 3 } & Aqueous(soaking) & 13.1 \\
\hline
\end{tabular}

Table 2: Inhibition 5-LOX by various extracts of Acalypha indica leaves.

\begin{tabular}{|c|c|c|c|c|c|c|c|}
\hline & $\begin{array}{l}\text { Conc. } \\
(\mu \mathrm{g} / \mathrm{ml})\end{array}$ & $\begin{array}{c}\text { Initial } \mathrm{O}_{2} \\
\text { conc. }\end{array}$ & $\begin{array}{c}\text { Final } \\
(\mu \mathrm{mol} / \mathrm{min})\end{array}$ & Difference. & Avg. & \multicolumn{2}{|c|}{ 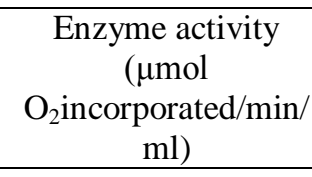 } \\
\hline Control & - & $\begin{array}{l}\text { a. } 239.84 \\
\text { b. } 250.05 \\
\end{array}$ & $\begin{array}{l}\text { a. } 56.32 \\
\text { b. } 61.66 \\
\end{array}$ & $\begin{array}{l}\text { a. } 183.52 \\
\text { b. } 188.39 \\
\end{array}$ & 185.95 & & 66 \\
\hline Sample & $\begin{array}{l}\text { Conc. } \\
(\mu \mathrm{g} / \mathrm{ml})\end{array}$ & $\begin{array}{c}\text { Initial } \mathrm{o}_{2} \\
\text { conc. }\end{array}$ & $\begin{array}{c}\text { Final } \\
(\mu \mathrm{mol} / \mathrm{min})\end{array}$ & Difference. & Avg. & $\begin{array}{c}\% \\
\text { Activity }\end{array}$ & $\begin{array}{c}\% \\
\text { Inhibition }\end{array}$ \\
\hline NDGA & 10 & 249.63 & 193.32 & 56.31 & - & 30.24 & 69.76 \\
\hline NDGA & 1 & 253.58 & 110.62 & 172.71 & & 92.88 & 7.12 \\
\hline $\mathrm{HX}$ & 100 & $\begin{array}{l}\text { a. } 195.90 \\
\text { b. } 198.24\end{array}$ & $\begin{array}{l}\text { a. } 67.43 \\
\text { b. } 83.89\end{array}$ & $\begin{array}{l}\text { a. } 128.47 \\
\text { b,114.35 }\end{array}$ & 121.49 & 65.29 & 34.71 \\
\hline EA & 100 & $\begin{array}{l}\text { a. } 228.64 \\
\text { b. } 231.83\end{array}$ & $\begin{array}{l}\text { a. } 112.53 \\
\text { b. } 115.78 \\
\end{array}$ & $\begin{array}{l}\text { a.116.11 } \\
\text { b.116.05 }\end{array}$ & 116.08 & 62.68 & 37.32 \\
\hline AQ & 100 & $\begin{array}{l}\text { a. } 256.24 \\
\text { b. } 259.02\end{array}$ & $\begin{array}{l}\text { a. } 76.37 \\
\text { b. } 85.44\end{array}$ & $\begin{array}{l}\text { a. } 179.87 \\
\text { b. } 173.58\end{array}$ & 176.73 & 95.43 & 4.57 \\
\hline Et.SK & 100 & $\begin{array}{l}\text { a. } 203.23 \\
\text { b. } 197.30\end{array}$ & $\begin{array}{l}\text { a. } 68.15 \\
\text { b. } 75.69\end{array}$ & $\begin{array}{l}\text { a. } 135.08 \\
\text { b. } 173.58\end{array}$ & 128.34 & 69.30 & 30.70 \\
\hline
\end{tabular}

Table 3: 5-LOX inhibition by various extracts of Acalypha indica leaves.

\begin{tabular}{|c|c|c|c|c|c|c|c|}
\hline Sample & $\begin{array}{l}\text { Conc. } \\
(\mu \mathrm{g} / \mathrm{ml})\end{array}$ & $\begin{array}{l}\text { Initial } \mathrm{o}_{2} \\
\text { conc. }\end{array}$ & $\begin{array}{c}\text { Final } \\
(\mu \mathrm{mol} / \mathrm{min})\end{array}$ & Difference. & Avg. & \multicolumn{2}{|c|}{$\begin{array}{c}\text { Enzyme activity } \\
(\mu \mathrm{mol} \\
\mathrm{O}_{2} \text { incorporated } / \mathrm{min} / \\
\mathrm{ml})\end{array}$} \\
\hline Control & - & $\begin{array}{l}\text { a. } 202.2 \\
\text { b. } 203.92\end{array}$ & $\begin{array}{l}\text { a. } 61.43 \\
\text { b. } 85.92\end{array}$ & $\begin{array}{l}\text { a. } 141.97 \\
\text { b. } 118\end{array}$ & 129.99 & \multicolumn{2}{|c|}{17.94} \\
\hline Sample & $\begin{array}{l}\text { Conc. } \\
(\mu \mathrm{g} / \mathrm{ml})\end{array}$ & $\begin{array}{l}\text { Initial } o_{2} \\
\text { conc. }\end{array}$ & $\begin{array}{c}\text { Final } \\
(\mu \mathrm{mol} / \mathrm{min})\end{array}$ & Difference. & Avg. & $\begin{array}{c}\% \\
\text { Activit } \\
\mathrm{y}\end{array}$ & $\begin{array}{c}\% \\
\text { Inhibition }\end{array}$ \\
\hline NDGA & 10 & 200.79 & 153.01 & 47.78 & & 36.19 & 63.81 \\
\hline
\end{tabular}


Exploring the Anti-inflammatory and Anti-cancer compounds from the leaves of Acalypha indica

\begin{tabular}{|c|c|c|c|c|c|c|c|}
\hline NDGA & 1 & 203.92 & 85.92 & 118 & - & 90.86 & 9.14 \\
\hline ETSX & 100 & $\begin{array}{l}\text { a. } 183.78 \\
\text { b. } 179.89\end{array}$ & $\begin{array}{l}\text { a. } 70.86 \\
\text { b. } 56.02\end{array}$ & $\begin{array}{c}\text { a.112.92 } \\
\text { b.123.87 }\end{array}$ & 118.34 & 91.12 & 8.88 \\
\hline MTSK & 100 & $\begin{array}{l}\text { a.149.11 } \\
\text { b.162.73 }\end{array}$ & $\begin{array}{l}\text { a. } 45.53 \\
\text { b.62.56 }\end{array}$ & $\begin{array}{l}\text { a.103.58 } \\
\text { b.100.11 }\end{array}$ & 101.85 & 78.42 & 21.58 \\
\hline MTSX & 100 & $\begin{array}{l}\text { a. } 194.52 \\
\text { b. } 194.86\end{array}$ & $\begin{array}{l}\text { a. } 83.95 \\
\text { b. } 106.75\end{array}$ & $\begin{array}{l}\text { a. } 110.57 \\
\text { b. } 88.1\end{array}$ & 99.33 & 76.48 & 23.52 \\
\hline
\end{tabular}

Table 4: 15-LOX inhibition by various extracts of Acalypha indica leaves.

\begin{tabular}{|c|c|c|c|}
\hline $\begin{array}{l}\text { Concentration } \\
\mu \mathrm{g} / \mathrm{ml}\end{array}$ & \% Activity & \%Inhibition & $\mathrm{IC}_{50}$ Values \\
\hline \multicolumn{4}{|c|}{ Ethanol (Soxhlation) Extract of Acalypha indica } \\
\hline 1 & 58.84 & 41.16 & \multirow[t]{3}{*}{39.207} \\
\hline 10 & 53.4 & 46.60 & \\
\hline 100 & 42.5 & 57.55 & \\
\hline \multicolumn{4}{|c|}{ Ethanol (Soaking) Extract of Acalypha indica } \\
\hline 1 & 32.07 & 67.93 & \multirow[t]{3}{*}{28.3045} \\
\hline 10 & 31.77 & 68.23 & \\
\hline 100 & 29.88 & 70.8 & \\
\hline
\end{tabular}

2D Graph 3

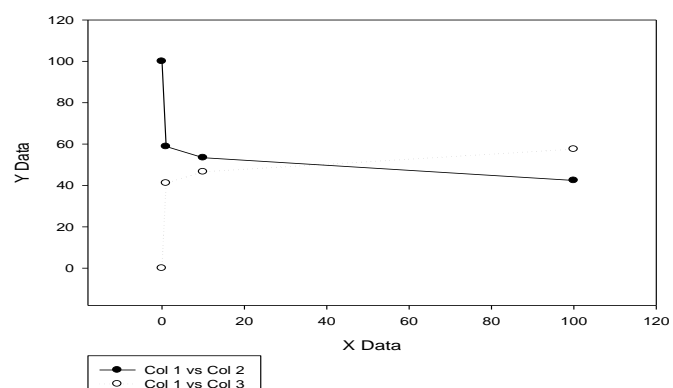

2D Graph 4

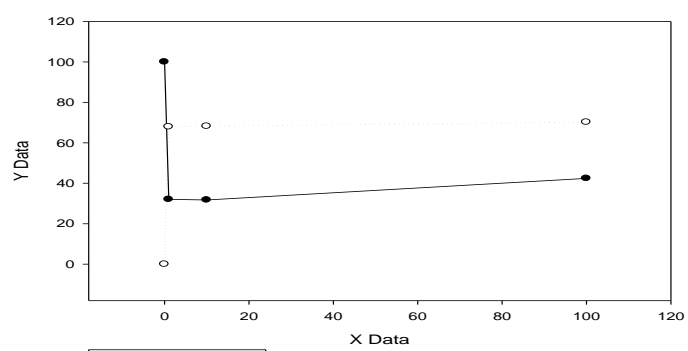

$\because-$ Col 1 vs $\mathrm{Col} 2$

Fig.1: Effect of ethanol (sox) extract on 15 LOX activity Fig.2: Effect of ethanol (soaking) extract on 15 LOX activity

$\mathbf{X}$ axis-Concentration of extracts in $\mu \mathrm{g} / \mathrm{ml}$ Y axis-\%Enzyme Activity/inhibition

Table 5: Enzyme Activity of COX 1 and $\operatorname{COX} 2$

\begin{tabular}{|c|c|}
\hline Enzyme Name & $\operatorname{Activity(} \square \mathbf{M o l} / \mathbf{m i n} / \mathbf{m L})$ \\
\hline COX 1 & 95.157 \\
\hline COX 2 & 34.50 \\
\hline
\end{tabular}

Table 6: COX-1 Inhibition by various extracts of Acalypha indica

\begin{tabular}{|c|c|c|c|}
\hline Concentration( $\square \mathrm{g} / \mathrm{ml})$ & \% Activity & \%inhibition & $\mathrm{IC}_{50}$ Values \\
\hline \multicolumn{4}{|c|}{ Ethyl acetate extract of Acalypha indica } \\
\hline 1 & 67.43 & 32.57 & \multirow{3}{*}{16.43} \\
\hline 10 & 51.90 & 48.10 & \\
\hline 100 & 27.74 & 72.26 & \\
\hline \multicolumn{4}{|c|}{ Hexane Extract of Acalypha Indica } \\
\hline 1 & 69.72 & 30.28 & \multirow{3}{*}{6.48} \\
\hline 10 & 37.66 & 62.34 & \\
\hline 100 & 13.23 & 86.77 & \\
\hline \multicolumn{4}{|c|}{ Ethanol(Soxhlation)extract of Acalypha indica } \\
\hline 1 & 84.73 & 15.27 & \multirow[t]{3}{*}{40.97} \\
\hline 10 & 61.23 & 38.68 & \\
\hline 100 & 28.24 & 71.75 & \\
\hline
\end{tabular}


Table 7:COX-2 Inhibition by various extracts of Acalypha indica

\begin{tabular}{|l|c|c|c|}
\hline Sample & Concentration $(\mu \mathrm{g} / \mathrm{mL})$ & \%Activity & \%Inhibition \\
\hline Ethylacetate ext. & 100 & 30.53 & 69.47 \\
\hline Hexane ext. & 100 & 30.53 & 69.47 \\
\hline Ethanol Sx.ext. & 100 & 68.77 & 31.23 \\
\hline
\end{tabular}

Hexane Extract-24Hr

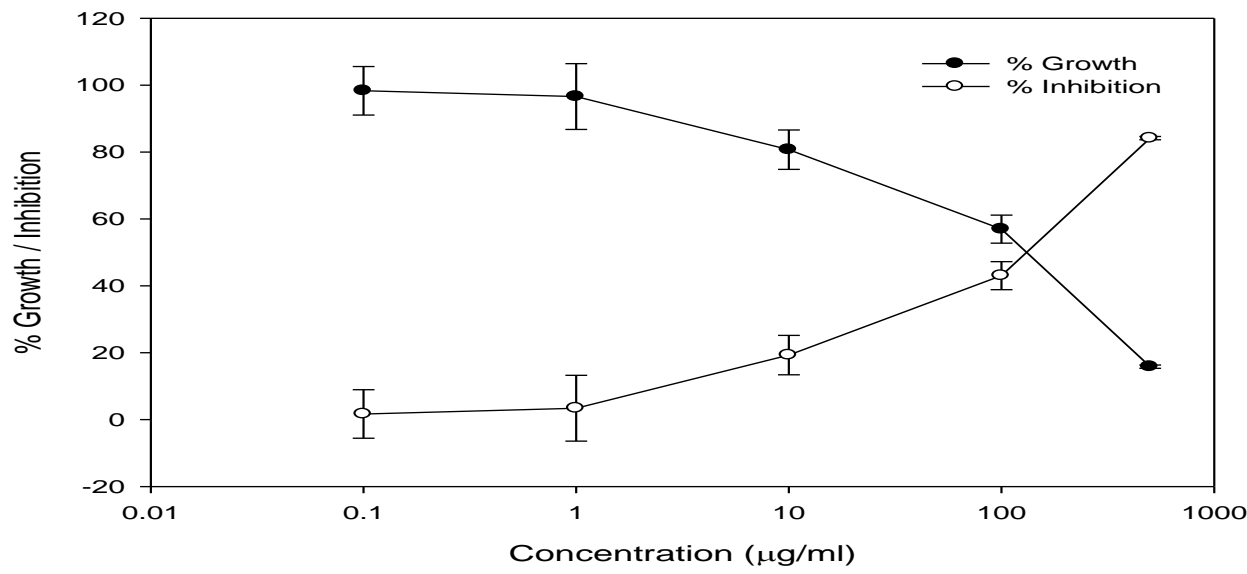

Fig 3: Measurement of effect of hexane extract of Acalyppha indica on the growth of A431 cells by MTT assay

Hexane Extract-48Hr

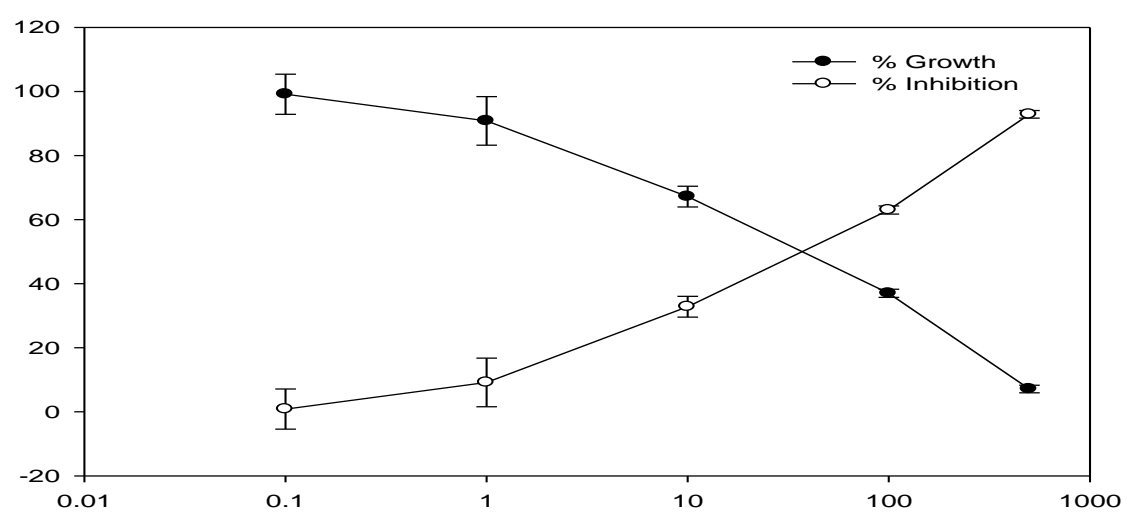

Fig.4: Measurement of effect of hexane extract of Acalyppha indica on the growth of A431 cells by MTT Ethyl Acetate Extract (24Hr)

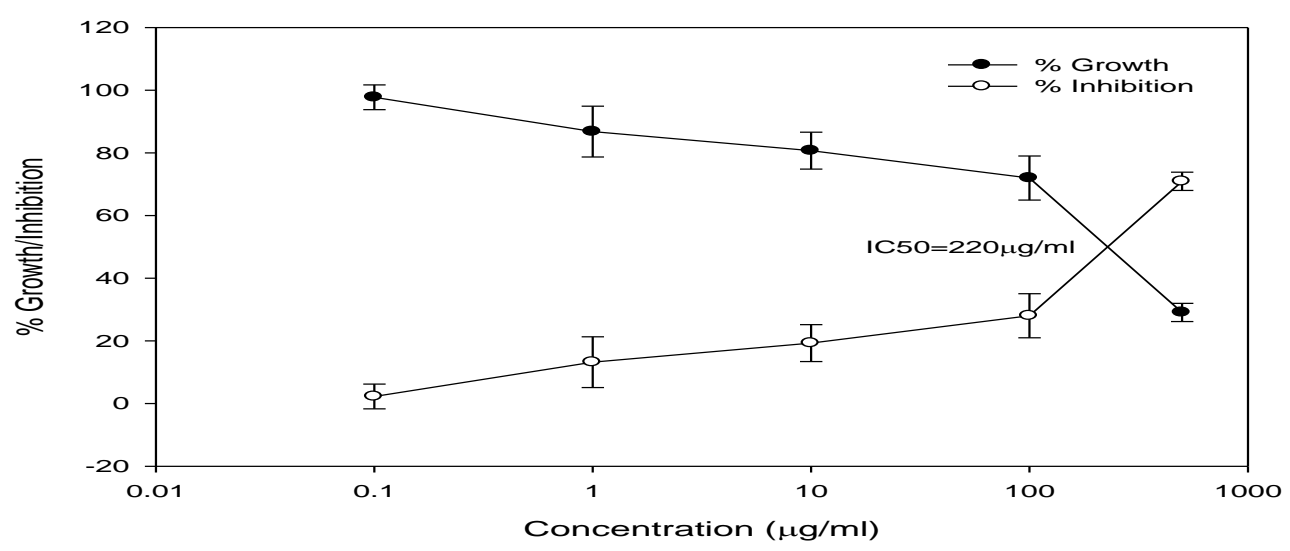

Fig.5: Measurement of effect of ethyl acetate extract of Acalyppha indica on the growth of A431 cells by MTT assay 
Ethyl Acetate Extract-48Hr

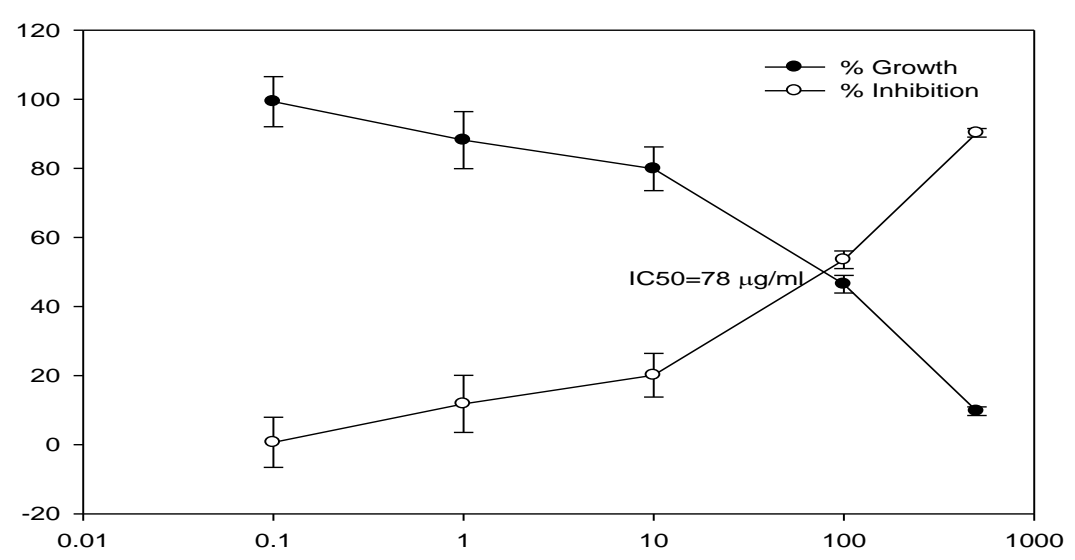

Fig.6:Measurement of effect of ethyl acetate extract of Acalypha indica on the growth of A431 cells by MTT assay

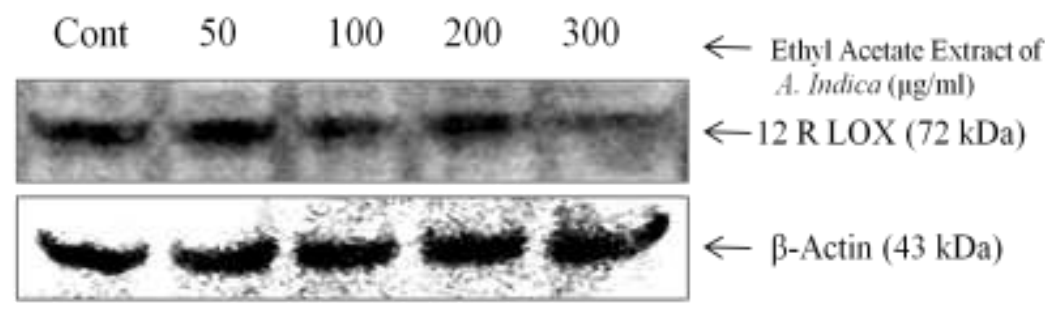

Fig: Western blot showing the effects of Ethyl Acetate extract of $A$. Indica on expression of $12 \mathrm{R}$ LOX in whole cells lysates of A431 cell line. Cells were incubated with different concentrations of compound $(50100,200$ and $300 \mu \mathrm{g} / \mathrm{ml})$ for $24 \mathrm{Hr}$. $\beta$-Actin was used as an internal control.

\section{Discussion}

The use of traditional medicinal plants in most developing countries for the maintenance of good health has been widely observed. A.indica is a traditional medicinal plant in India, used as antibacterial, anti-fungal activities. It is observed that this plant has anti-inflammatory and anti-cancer properties. It is also used to treat diabetes and other diseases and disorders.

Eicosanoids are potent biologically active AA derived lipid mediators that are intimately involved in inflammation and cancer. COX and 5-LOX are the key enzymes in the AA metabolism. COX enzyme exists in two distinct isoforms, COX-1 and COX-2. COX-1 is expressed constitutively in nearly all mammalian tissues and is the source of prostaglandins central to "housekeeping" functions such as renal water reabsorption, vascular homeostasis, and gastric protection (Smith et al., 1996). COX-2, an inducible enzyme, is mainly expressed under pathological conditions such as inflammation and carcinogenesis.

In the light of key role played by COX-2 in inflammation, COX-2 Inhibitors were developed as novel NSAIDs without gastric side effects that are associated with the conventional NSAIDs. In addition to their role in inflammation, selective inhibitors of COX-2 have been demonstrated to induce apoptosis in variety of cancer cell lines including colon, stomach, prostate, and breast (Elder et al., 1997). 5-LOX is involved in the biosynthesis of LTs, pro-inflammatory mediators participating in various forms of acute and sub acute inflammation. 5-HETE, product of 5-LOX was shown to be a potential survival factor for prostate cancer cells and inhibition of 5-LOX triggered massive apoptosis (Ghosh et al., 1998). Both 5-LOX and COX-2 are coexpressed and up-regulated in inflammation and in many forms of human cancers, including colon, prostate, breast and lung cancers and form targets for development of anti-inflammatory and anti-cancer drugs (Pommery et al., 2004). Moreover, COX-2 inhibition by celecoxib in cancer cell lines was shown to increase the formation of 5-HETEs, which is having tumor cell proliferative property (Ye et al., 2005). Hence there is need for the development of potent COX-LOX dual inhibitors without side effects.

In our attempt to isolate a natural product with COX-LOX dual inhibition, Acalypha indica is identified as a potential source. The studies with different extracts of Acalypha indica showed potent inhibition to 5-LOX, 15-LOX and COX-1. The 5-LOXinhibition of four extracts of A.indica in increasing order is as follows: 
aqueous extract <ethanol (sx) extract $<$ methanol (sk) extract $<$ methanol (sx) extract $<$ ethanol (sk) extract < hexane extract < ethyl acetate extract. In the present study, our results have shown that extracts of inhibited 15LOX. Ethanol soxhlation and soaking extract showed more potent inhibition when compared to ethyl acetate and hexane extracts. The 15-LOX inhibition of four extracts of $A$. indica in increasing order is as follows: water extract $<$ hexane < ethyl acetate extract < ethanol extract. Hexane, ethyl acetate and ethanol soxhlation extracts showed potent inhibition to COX-1. Among this hexane extract showed potent enzymatic inhibition to COX-1 with IC50 - 6.48 $\mu \mathrm{g} / \mathrm{ml}$. Ethyl acetate and ethanol soxhlation extracts' IC50 values $16.43 \mu \mathrm{g} / \mathrm{ml}, 40.97 \mu \mathrm{g} / \mathrm{ml}$ respectively. Here aqueous extract showed moderate enzymatic inhibition. The COX-1 inhibition of four extracts of $A$. indica in increasing order is as follows: water extract < ethanol (sx) extract < ethyl acetate extract $<$ hexane extract. Hexane, ethyl acetate and ethanol soxhlation extracts showed potent inhibition to COX-2. Among this hexane extract and ethyl acetate showed potent enzymatic inhibition to COX-2. COX-2 inhibition of 3 extracts of $A$. indica in increasing order is as follows- ethanol (sx) extract < ethyl acetate and hexane extract.

From the above results it is observed that the ethyl acetate extract and hexane extract of $A$. indica showed potent enzyme inhibition to 5-LOX and COX-2 enzymes when compared to 15-LOX enzyme. Hexane extract of $A$. indica showed potent enzyme inhibition of COX-1 enzymes. Ethanol (sx) extract of $A$. indica showed potent enzyme inhibition to both 15-LOX and COX-1, no inhibition to 5-LOX enzyme.

\section{Conclusion}

The present study reveals that the leaves of $A$. indica contain potent anti-inflammatory compounds as evidenced by the potent inhibition of lipoxygenases and cyclooxygenases. These compounds appear to be nonpolar in nature as they were extracted in to non-polar solvents like hexane, ethyl acetate and ethanol, methanol. Further studies, however, are needed to identify the specific molecules involved in the inhibition of these enzymes.

\section{References}

[1] Amin, Ashok R, Attur, Mukundan, Abramson, Steven B. Nitric oxide synthase and cyclooxygenases: distribution, regulation, and intervention in arthritis. Current Opinion in Rheumatology (1997); Vol 11(3).

[2] Bradford MM. A rapid and sensitive method for the quantification of microgram quantities of protein utilizing the principal of protein dye binding. Anal Biochem (1976), Vol 72: 248-254.

[3] Crofford LJ. COX-1 and COX-2 tissue expression: implications and predictions. J Rheumatol Suppl. (1997), Vol.49:15-9.

[4] Kapoor, L. D. \{CRC $\}$ Handbook of Ayurvedic medicinal plants(1990).

[5] Mukherjee D. Selective cyclooxygenase-2 (COX-2) inhibitors and potential risk of cardiovascular events. Biochem. Pharmacol (2002),Vol. 63: 817-21.

[6] Reddy CM, Subhashini J, Mahipal SVK, Bhat VB, Srinivas Reddy P, Kiranmai G, Madyastha KM, Reddanna P. C-Phycocyanin, a selective cyclooxygenase-2 inhibitor, induces apoptosis in lipopolysaccharide-stimulated RAW 264.7 macrophages. Biochem Biophys Res Commun (2003),Vol. 304: 385-392.

[7] Reddy DB, Reddy TC, Jyotsna G, et al, Chebulagic acid, a COX-LOX dual inhibitor isolated from the fruits of Terminalia chebula Retz., induces apoptosis in COLO-205 cell line. J Ethnopharmacol (2009),Vol.124(3):506-12.

[8] Reddy CM, Bhat VB, Kiranmai G, Reddy MN, Reddanna P, Madyastha KM. Selective inhibition of cyclooxygenase-2 by Cphycocyanin, a biliprotein from Spirulina platensis. Biochem Biophys Res Commun (2000), Vol 277:599-603.

[9] Simon LS. COX-2 inhibitors. Are they non-steroidal anti-inflammatory drugs with a better safety profile? Gastroenterol. Clin. North Am (2001, Vol. 30: 1011-25.

[10] Sreekanth D, Arunasree MK, Roy KR, Chandramohan Reddy T, Reddy GV, Reddanna P. Betanin a betacyanin pigment purified from fruits of Opuntia ficus-indica induces apoptosis in human chronic myeloid leukemia Cell line-K562 Phytomedicine(2007) ,Vol 14:739-46.

[11] Williams C, Shattuck-Brandt RL, DuBois RN. The role of COX-2 in intestinal cancer. Ann N Y Acad Science(1999), Vol 889:7283 . 